\title{
Socoi-Economic and Cultural Constraints in Higher Education of Females in Pakistan: (A Case Study of Dera Ghazi Khan)
}

\author{
Shahabia Jamshaid*1 \\ ${ }^{1}$ Department of Sociology, Ghazi University Dera Ghazi Khan, Pakistan \\ *Corresponding Author: shahabiajamshaid@gmail.com
}

\begin{abstract}
Education is the requirement of all men and women to compete in this era of knowledge as without education, survival is very difficult for both male and female. In rural areas of Pakistan female being subjugated under the patriarchal eastern society are most vulnerable condition. Their vulnerability is at worst in the areas where mainly tribal life form exists. Dera Ghazi Khan is one of the districts of Punjab, where tribal life style exists. Women under tribal regulations have a little access to education while very low access to higher education. The study was conducted in Dera Ghazi Khan, Punjab, Pakistan and it was conducted by adopting quantitative research method; a structured questionnaire was developed to collect data from 400 female. The study was an effort to explore the issues which restrict female from higher education. The major findings revealed that female face many problems and constraints in their higher education, such as long distance, less awareness about higher education, domestic responsibilities, early marriage and also female face issues regarding their security.
\end{abstract}

Key words: Socio-Economic, Cultural, Constraints, Higher Education.

\section{Introduction}

Female higher education in Pakistan is an important issue as majority of female education in the country does not have access to higher education due to different socio-economic constraints. In Pakistani culture in which patriarchy families are prominent and head of household mostly remain men, so men hold the family affairs and make decision about family members. From the origin of human life male and female are the two sexes (sex is a biological term, differentiate men and women) exist in the world. These two sexes have their role and worth in society, men remain prominent in the world throughout history (Begum, 2002). 
The education can usually recognize as a very important tool for progress. Therefore, the essential characteristics of education in ornamental social financial and human progress has common intrinsic value education is a basic right of all person. Today, those societies have excelled in all field of life, where men and women can obtain equal opportunities for higher education (Forster et al., 2012).

In Pakistan, female is not politically strong, also socially bonded and cannot move easily even they are culturally restrained so female deprived to get education (Ahmad et al, 2014). The women are typically busy in different domestic work like infant care, protection, washing clothes, attend guest and cooking. Therefore, at home a woman cannot fulfill all the requirements, so the younger girls mostly attach with their mother, consequently effect the girl's education (Ghosh, 2008).

The difference between men and women education because of gender based inequalities and discrimination prevails in the rural areas. The traditional areas dislike, their women should get higher education. Mostly, boys get higher education so, this reason effect the women enrolment in educational institute and decrease the women literacy rate. Moreover, Parents spend their money on son's education but not on daughter's education because they would marry to another home and only perform all domestic responsibilities. So, it's useless to invest money on their higher education (Ahmad, Akhtar, Rashid and Zia, 2013).

In Pakistani society, man always dominate in all aspect of life. Especially after marriage man makes all decisions, man do not listen female's view, so females are restricted and cannot enjoy freedom and their life even cannot get higher education because they cannot manage their domestic life and education at a time (Yousaf and Schmiede, 2016). Moreover, in Pakistani traditional system man is the head of household and does not allow that girls should get higher education. Because parents assume that the education play an integral role in the boy's life as they face earning problems in their life because earning is the men duty so education is not necessary for girls. These reasons restrict the females from getting higher education.

Parveen, (2008) said that rural women face a number of problems for getting higher education, because tradition create constraints for her in getting the higher education. Farid et al (2014), females who live in rural areas of Pakistan face many social, cultural and economic 
Socoi - Economic and Cultural Constraints in Higher Education of Females in Pakistan: (A Case Study of Dera Ghazi Khan)

barriers, so they are not permitted to get higher education. Therefore, present study has been designed to identify the socio-economic constraints faced by females in access to higher education and to explore the constraints faced by female in access to higher education due to patriarchal system.

\section{Hypothesis}

i. Lower the income, lower will be the chances of higher education.

ii. Higher the Patriarchal system, lower will be the female higher education.

\section{Theoretical Background of the Study}

Michel Foucault gave a new dimension to power which he related with knowledge. He defined the use of knowledge as an instrument of power. He said power is everywhere diffused and embodied in discourse knowledge and regimes of truth (Foucault, 1991).

Similar situation has been found in the study, where patriarchy society has control over the scientific knowledge and uses this power to keep the women subjugated and deprived. Hence, they would not be able to raise their voice to obtain the basic rights like health, education, reproductive health rights, rights of inheritance and right to live independently. The political regimes usually use religious knowledge to gain power over the deprived women by interpreting religious knowledge in their own ways to explain, how men are powerful and women are not/less powerful in the definitions of religion. By this they gain not only the control over women but also over their all kinds of individual, political, social, economic and medical rights which they are subject to be provided otherwise.

\section{Materials and Methods}

The study was conducted by adopting quantitative research method and structured questionnaire was developed. To collect the data, 400 female students from four Degree College for Women were selected from D. G. Khan. Moreover, female was selected by adopting random sampling technique. Data was analyzed by using SPSS software and statistical test was applied to check the result of study. The problems which are the big hurdles in the way to get higher education for females are presented in the Table 1.

Table 1: Difficulties for getting higher education 


\begin{tabular}{|c|c|c|}
\hline Category & Frequency & Percentage \\
\hline \multicolumn{3}{|c|}{ Educational Expenditure } \\
\hline To great extent & 252 & 63.0 \\
\hline To some extent & 93 & 23.2 \\
\hline Not at all & 55 & 13.7 \\
\hline Total & 400 & 100 \\
\hline \multicolumn{3}{|c|}{ Transport Problem } \\
\hline To great extent & 298 & 74.5 \\
\hline To some extent & 62 & 15.5 \\
\hline Not at all & 40 & 10.0 \\
\hline Total & 400 & 100 \\
\hline \multicolumn{3}{|c|}{ Unfavorable Attitude of Parents } \\
\hline To great extent & 6 & 1.5 \\
\hline To some extent & 128 & 32.0 \\
\hline Not at all & 266 & 66.5 \\
\hline Total & 400 & 100 \\
\hline \multicolumn{3}{|c|}{ Unfavorable Attitude of In-laws } \\
\hline Respondents do not have in-laws & 390 & 97.5 \\
\hline To great extent & 7 & 1.8 \\
\hline To some extent & 3 & 0.7 \\
\hline Total & 400 & 100 \\
\hline \multicolumn{3}{|c|}{ Unfavorable Attitude of Husband } \\
\hline Respondents do not have husband & 390 & 97.5 \\
\hline To great extent & 3 & 0.8 \\
\hline To some extent & 7 & 1.7 \\
\hline Total & 400 & 100 \\
\hline
\end{tabular}


Socoi - Economic and Cultural Constraints in Higher Education of Females in Pakistan: (A Case Study of Dera Ghazi Khan)

\begin{tabular}{|l|c|c|}
\hline \multicolumn{3}{|c|}{ Domestic Responsibilities } \\
\hline To great extent & 27 & 6.6 \\
\hline To some extent & 121 & 30.3 \\
\hline Not at all & 252 & 63.1 \\
\hline Total & 400 & 100.0 \\
\hline
\end{tabular}

Source: Author(s) calculation

The results show that more than half $(63.0 \%)$ of the respondents answered "to great extent" educational expenditure could create difficulties in their education, in rural areas almost parents could not afford educational expenditure of their children because irrigation was source of income and it was not enough to fulfill the family basic needs and also high educational expenditure. While $23.3 \%$ of the respondents answered "to some extent" they were facing difficulties in getting education because of educational expenditure. Respondent's parents either were doing own business or had enough property that parents could afford educational expenditure and $13.7 \%$ of the respondents answered "not at all" they were not facing any problem because of educational expenditure.

In rural areas females were restricted in mobility. They could not move easily anywhere or without man, females could not go outside. Majority (74.5\%) of the respondents answered "to great extent" they were facing problem in getting education because of transport problem. Long distance from home to educational institution, especially for girls is the main problem in getting education (Oxaal, 1997). Only 15.5\% of the respondents answered "to some extent" transport problem might be a hurdle in getting education because they said if no one could drop them in educational institutions they could hire any other source of transportation, while $10 \%$ of the respondents answered that transport was "not at all" a problem in getting education.

Parents attitude was some time unfavorable for the children education, particularly parent's attitude could be negative for daughter's education (Khan, 2007.) There are many reasons which change parent's attitude toward their children's education, like parents spend more money on son's education and give preference to daughters in domestic work. A small percentage $(1.5 \%)$ of the respondents answered "to great extent" their parent's attitude was unfavorable, $32.0 \%$ of the respondents answered "to some extent" and more than half $(66.5 \%)$ of 
the respondents answered "not at all" parents' attitude was not unfavorable towards their education. In our culture, daughters are mostly attached with their mothers and they assist their mother in domestic work, so these attachments, discrimination and gender-based inequality start from this stage and destroy the girl's education career and creates constraints for girls in education (Juliette and Harvey, 2011).

The respondents who were married and getting education were asked if they were facing problem in their education because of unfavorable attitude of in-laws and husbands, in response to this a high majority (97.5\%) of the respondents were not married. And about $1.8 \%$ of the respondents said "to great extent" in-laws' attitude was unfavorable towards their education because their expectations were so high and demand that girl should involve in whole domestic responsibilities because of that respondents could not study and were facing problem in getting education. Only $0.7 \%$ of the respondents answered "to some extent" their in-laws" attitude was negative but some time, they did favor them in education. Similarly, about $97.5 \%$ of the respondents answered "to great extent" their husband's attitude was unfavorable towards their getting education. They do not like their study and want their wives to stay at home and perform domestic responsibilities. And only $1.7 \%$ of the respondents answered "to some extent" their husband's unfavorable attitude create problem in getting education. Females are mostly performing their domestic work instead of males; these domestic responsibilities can create many problems in their studies. Only $6.6 \%$ of the respondents answered "to great extent", $30.3 \%$ of the respondents answered "to some extent" and more than half $(63.1 \%)$ of the respondents answered "not at all" domestic responsibilities were not creating problems in their getting education.

Table 2: Restrictions in getting higher education 
Socoi - Economic and Cultural Constraints in Higher Education of Females in Pakistan: (A Case Study of Dera Ghazi Khan)

\begin{tabular}{|c|c|c|}
\hline Category & Frequency & Percentage \\
\hline \multicolumn{3}{|c|}{ Domestic Responsibilities } \\
\hline To great extent & 92 & 23.0 \\
\hline To some extent & 138 & 34.5 \\
\hline Not at all & 170 & 42.5 \\
\hline Total & 400 & 100 \\
\hline \multicolumn{3}{|c|}{ Economic Reason } \\
\hline To great extent & 252 & 63.0 \\
\hline To some extent & 99 & 24.8 \\
\hline Not at all & 49 & 12.2 \\
\hline Total & 400 & 100 \\
\hline \multicolumn{3}{|c|}{ No Interest of Parents } \\
\hline To great extent & 3 & 0.8 \\
\hline To some extent & 192 & 48.0 \\
\hline Not at all & 205 & 51.2 \\
\hline Total & 400 & 100 \\
\hline \multicolumn{3}{|c|}{ Self no Interest } \\
\hline To great extent & 3 & 0.8 \\
\hline To some extent & 40 & 10.0 \\
\hline Not at all & 357 & 89.2 \\
\hline Total & 400 & 100 \\
\hline \multicolumn{3}{|c|}{ Family Restrictions } \\
\hline To great extent & 111 & 27.8 \\
\hline To some extent & 194 & 48.5 \\
\hline Not at all & 95 & 23.8 \\
\hline Total & 400 & 100 \\
\hline
\end{tabular}


Jamshaid, S. (2020)

\begin{tabular}{|l|c|c|}
\hline \multicolumn{2}{|c|}{ No Awareness } \\
\hline To great extent & 220 & 55.0 \\
\hline To some extent & 123 & 30.8 \\
\hline Not at all & 57 & 14.2 \\
\hline Total & 400 & 100 \\
\hline \multicolumn{2}{|c|}{ Long Distance } \\
\hline To great extent & 252 & 63.0 \\
\hline To some extent & 105 & 26.3 \\
\hline Not at all & 43 & 10.7 \\
\hline Total & 400 & 100.0 \\
\hline
\end{tabular}

Source: Author(s) calculation

The result elaborates that about $23.0 \%$ of the respondents answered "to great extent" domestic reason was a main restriction that they could not get higher education because respondents performed a lot of work at home. Secondly, some time because of mother illness, they could not leave her alone at home and many other reasons restricted them to continue their education. While $34.5 \%$ respondents answered "to some extent "domestic reasons create restriction in getting higher education because in rural areas there were many domestic problems and reasons and females were deprived from higher education.

And about $42.5 \%$ respondents answered "not at all" domestic reasons did not restrict them for getting higher education. Similarly, $63.0 \%$ respondents answered "to great extent" economic reason was a main restriction in their higher education because they belonged to poor families and expenditure of higher education was not affordable for their parents. However, $24.8 \%$ respondents answered "to some extent "economic reason created restrictions in their higher education. Mostly respondents who could continue their higher education have given many sacrifices. Some of those respondents (12.2\%), who were well established and their parents could afford their higher education expenditure, answered "not at all" economic reason restrict them from getting higher education. 
Socoi - Economic and Cultural Constraints in Higher Education of Females in Pakistan: (A Case Study of Dera Ghazi Khan)

Above table also shows that $0.8 \%$ of the respondents answered "to great extent" their parents did not take interest in their children could continue higher education, parents just want that their children got school education and it was enough. Little less than half (48.0\%) of the respondents answered "to some extent" their parents may not take interest in their getting higher education and that situation could restrict them for getting higher education. More than half $(51.2 \%)$ of the respondents answered "not at all" no interest of their parents in education could restrict them for further higher education. Similarly, table also elaborates that $0.8 \%$ of the respondents answered "to great extent" they have no wish to get higher education, only ten percent of the respondents answered "to some extent" they did not want to get higher education. Sometime their parents did want that their daughters should get further education but respondents did not want, so lack of interest of the respondents created hurdle in their higher education. While majority $(89.2 \%)$ of the respondents answered "not at all."

Family restrictions also create many problems in higher education of female like many families are more conscious about girls and they do not send them for higher education to other cities and trend of early marriage is also considered in family restrictions and many more. Less than half $(27.8 \%)$ of the respondents answered "to great extent" family restrictions created many obstacles in their higher education because females were bound to follow all the family restrictions. Less than half (48.5\%) of the respondents answered "to some extent", while $23.8 \%$ respondents answered "not at all" there were no any family restriction which created difficulties in their higher education.

In rural areas many students remain deprived from higher education because of lack of awareness about education that where universities are, when admissions are open, which courses are offered in which university and many more. More than half of the respondents $(55.0 \%)$ answered "to great extent" it was absolutely correct that they were deprived of awareness about higher education, $30.8 \%$ of the respondents answered "to some extent" while $14.2 \%$ of the respondents answered that lack of awareness "not at all" created any restrictions because those respondents belonged to educated families where all people were getting education in different universities and they got all information about education very easily.

Long distance is another main hurdle in female higher education. Many parents do not send their daughters very far for higher education because there is no any university in rural 
areas. Where female can go easily and get higher education so, parents feel fear to send their daughters to other cities and long distance to educational institution can create restriction in female higher education. Most of the respondents (63.0\%) answered "to great extent" they were facing difficulties in their higher education because there was no university in their area where they get higher education and they were not allowed to stay in hostel, so long distance from home to university could create restriction in their higher education. About $26.3 \%$ of the respondents gave answer "to some extent" they could face problems for getting higher education because of long distance. While only $10.7 \%$ of the respondents answered that distance is "not at all" an issue for getting higher education, they could move with their family to other cities for getting higher education. So, in rural areas many parents do not agree to send their daughters for education because they think female should remain at home and perform all domestic work hence parents give preference to their son's for education.

Table 3: Association between parental attitudes towards higher education of female.

\begin{tabular}{|c|c|c|c|c|}
\hline \multicolumn{3}{|c|}{ Patriarchy } & \multicolumn{2}{|c|}{ Higher Education of Female } \\
\hline & To Great Extent & To Some Extent & Not at All & Total \\
\hline Son & 149 & 91 & 39 & 279 \\
\hline Daughters & 9 & 6 & 10 & 25 \\
\hline Both & 42 & 38 & 16 & 96 \\
\hline Total & 200 & 135 & 65 & 400 \\
\hline \multicolumn{5}{|c|}{$\begin{array}{lll}\text { Chi - } \text { square }=\mathbf{1 3 5 . 2 6 1} & \mathbf{d f}=\mathbf{4} & \text { level of } \\
\text { significance }=\mathbf{0 . 0 1} \text { As } p=0.00<0.05 & \text { At } \alpha=0.05 \& \text { df }=4 \quad \text { Where } n=400 & \end{array}$} \\
\hline
\end{tabular}

Source: Author(s) calculation

Table 3 represents the relationship between choice to get higher education and to whom parents give preference for higher education. The majority of respondents about 149 answered "to great extent" their parents give preference to son for higher education. There are many societies in Pakistan those give preference to son for higher education because parents want to invest money on their son not on daughters. They think that daughters will get married to another home but son will remain with them for whole life and he will earn money for them, they feel secure and relaxed to spend money on son's education. Pande and Astone (2001) stated that parents like to 
Socoi - Economic and Cultural Constraints in Higher Education of Females in Pakistan: (A Case Study of Dera Ghazi Khan)

spend money on son than daughters and wish he get higher education when he will avail education then parents can get secure future with him because after getting education son would get good job and support them financially.

Table 4: Association between choice of female higher education and parents can afford higher education expenditure

\begin{tabular}{|l|c|c|c|c|}
\hline \multicolumn{2}{|c|}{$\begin{array}{l}\text { Parents Affordability Towards Higher } \\
\text { Education }\end{array}$} & \multicolumn{3}{c|}{ Opportunity of Higher Education } \\
\hline & To Great Extent & To Some Extent & Not at All & Total \\
\hline To great extent & $(52) 68.4 \%$ & $(21) 27.6 \%$ & $(3) 3.9 \%$ & $(76) 100.0 \%$ \\
\hline To some extent & $(97) 49.7 \%$ & $(83) 42.6 \%$ & $(15) 7.7 \%$ & $(195) 100.0 \%$ \\
\hline Not at all & $(9) 7.0 \%$ & $(89) 69.0 \%$ & $(31) 24.0 \%$ & $(129) 100.0 \%$ \\
\hline Total & $(158) 39.5 \%$ & $(193) 48.2 \%$ & $(49) 12.2 \%$ & $(400) 100.0 \%$ \\
\hline $\begin{array}{l}\text { Chi }- \text { square }=97.523 \\
0.00\end{array}$ \\
As p=0.00<0.05
\end{tabular}

Source: Author(s) calculation

According to table 4 elaborates the relationship between choice to get higher education and parents affording expenditures for higher education. The $69.0 \%$ respondents answered "not at all" their parents cannot afford their expenditure of higher education because of low income status.

In rural areas people are deprived of basic needs like they are not able to afford a proper diet for their children and themselves and they cannot approach health facilities. Even if they want to give good education to their children's, they cannot afford expenditure of education specially girls are victim of this situation. Parents are not ready to give higher education of their daughters. In this society where basic needs are also not available girls remain quiet and do not wish and choice to get higher education. Many females cannot get higher education in Pakistan because there are many constraints which create hurdles in their education, especially economic reasons are main cause and parents cannot afford expenditure of education and females are unable to achieve further education (Nayak and Nair, 2005). 
In the rural areas it is common that parents invest money on son because in future he would be managing all domestic responsibilities and will be giving all facilities like food, security, dresses and health treatment to his parents when they become old. Hence parents do not invest on daughter's education because they will get marry to someone in other home (Shekh, 2003).

\section{Recommendations}

Here are some recommendations which can help the policy makers to improve female higher education in Pakistan and other areas of world, where there are similar socio-economic and cultural is prevailing:

i. Separate male female higher education institutions should be established to decrease the barriers like vail (Pardah), traditional criticism on co-education etc.

ii. Higher education institutions should have facility of girl hostels to accommodate 100 percent of their female students.

iii. Special funds should be given to higher education institutions by federal/provincial governments for transportations/pick \& drop of all female students at least within the circle of 10-15 kilometers.

iv. Need based scholarships should be promoted to give opportunity to female students from poor families to get chance of higher education.

v. Free choice for subject selection should give female students to create interest among them for getting higher education.

vi. Separate cafeterias, library sitting arrangements and play grounds should be arranged in the higher education institution, where there is co-education.

vii. Media awareness campaigns would be useful tool to create awareness among the parents regarding female higher education. Media messages and videos should be finalized by cultural experts (sociologists/anthropologists) to make them culturally appropriate and language to be used should be local and easy to understand for all social groups of focused areas. 
Socoi - Economic and Cultural Constraints in Higher Education of Females in Pakistan: (A Case Study of Dera Ghazi Khan)

viii. Employment opportunities should be increased for women and they should give the choice for the selection of work stations/posting places, so that they may feel comfortable and it will also encourage the parents to permit their daughters for higher education and job.

\section{Conclusion}

Female higher education in Pakistan is an important issue as majority of female population in country does not have access to higher education due to different sociocultural and economic constrains. The study showed that majority of female could not get higher education due to patriarchal system. Parents of respondents prefer that their daughter get Islamic education at Madarsa instead of at any formal educational institution. Although parents acknowledge their girl higher education but they could not give them proper resources for getting higher education because of many problems and high educational expenditure which they could not afford, about $27.5 \%$ respondents answered their parents gave preference to son for getting higher education because parents only wanted to invest money on their son's education.

While more than half parents gave preference to both but due to socio-economic and cultural constraints female deprived to get higher education. About $95.5 \%$ respondents answered that they want to get higher education because parents wanted their daughters to get respectable status in the society and it will only be possible through higher education but lack of opportunities, patriarchy system, mobility restriction for female in society, vail (Pardah), early marriage and affordability of public transport is also major barrier in getting higher education. Malik (2002) said that more parents prefer daughter's higher education because their daughters can obtain good jobs and secure their future.

Similarly, they can achieve satisfaction and superior standard of living in the society. Nguyen and Wodon (2015) said that when girls are married early, they can't carry their education, it can lead to decrease the percentage points 4-6 in getting of secondary school education foe girls. 
Jamshaid, S. (2020)

\section{Acknowledgement}

I am thankful to the editorial board for the support and guideline.

\section{References}

Ahmad, I., Said, H., Hussain, A., \& Khan, S. (2014). Barriers to Co-Education in Pakistan and its Implications on Girls Education: Critical Review of Literature. Science International, 26(1), 30-45.

Ahmad, S. A., Sayed, M. H., Khan, M. H., Karim, M. N., Haque, M. A., Bhuiyan, M. S., ... \& Faruquee, M. H. (2007). Sociocultural aspects of arsenicosis in Bangladesh: community perspective. Journal of Environmental Science and Health, Part A, 42(12), 1945-1958.

Dijkstra, G. A., \& Hanmer, L. L. (1997). Measuring socio-economic gender inequality: towards an alternative to the UNDP gender-related development index. ISS Working Paper Series/General Series, 251, 1-30.

Farid, T., Anwar, M. N., Iqbal, S., Jan, M., \& Khattak, I. (2014). Socio Economic Problems Faced by Rural Women in Getting Higher Education (A Case Study of District Karak). International Asian Research Journal, 2(4), 31-40.

Foucault, M. (1991). Politics and Ethics': An Interview'in Rabinow, P.(ed) The Foucault Reader: An Introduction to Foucault's Thought.

Forster, P., \& Offei-Ansah, C. (2012). Family roles and coping strategies of female students in Ghanaian Public Universities. International Journal of Academic Research in Business and

Social Sciences, 2(5), 191-205.

Khan, H. A. M. A. D., Ali, A. K. H. T. A. R., Khan, R., \& Zia, Y. A. (2013). Social constraints to female higher education in Pakhtoon society. European journal of Business and Social Sciences, 2(4), 25-31.

Myers, J., \& Rowan, H. (2011). Breaking Vows: Early and Forced Marriage and Girls. Education'.

\section{London: DFID.}

MALIK, S. (2002). Factors affecting the development of female higher education in Pakistan and future strategies (Doctoral dissertation, ARID AGRICULTURE UNIVERSITY, RAWALPINDI).

Nayak, S. (2005). Women's Empowerment in India. Pointer Publishers.

Nguyen, M.C and Q. Wodon. (2015). Global and regional trends in child marriage. he Review of Faith and International Affairs;1(3),5t1`6-11

Oxaal, Z. (1997). Education and poverty: A gender analysis (Vol. 53). Sussex: Institute of Development Studies at the University of Sussex. 
Socoi - Economic and Cultural Constraints in Higher Education of Females in Pakistan: (A Case Study of Dera Ghazi Khan)

Pande, R. P., \& Astone, N. M. (2007). Explaining son preference in rural India: the independent role of structural versus individual factors. Population Research and Policy Review, 26(1), 1-29.

Parveen, S. (2008). Female education and national development: As viewed by women activists and advocates. Bulletin of Education \& Research, 30(1), 33-41.

Yousaf, R., \& Schmiede, R. (2016). Underrepresentation of women at academic excellence and position of power: role of harassment and glass ceiling. Open Journal of Social

Sciences, 4(2), 173-185.

\section{Quantitative Forecasting Methods}

It is a statistical technique to make predictions about the future which uses numerical measures and prior effects to predict future events. These techniques are based on models of mathematics and in nature are mostly objective. They are highly dependent on mathematical calculations.

There are two types of quantitative forecasting methods which are listed below:

1. Time-Series Models - These models examine the past data patterns and forecast the future on the basis of underlying patterns that are obtained from those data. There are many types of time series models like Simple and weighted moving average, seasonal indexes, trend projections, simple mean and exponential smoothing.

2. Associative Models - are also known as casual models. The model assumes that the variable that is being forecasted is associated with other variables. The predictions are made based on these associations. The linear regression is one of the simplest forms of an associative model of forecasting. This regression line forecasts the dependent variable based on the selected value of the independent variable.

Quantitative forecasting methods are very easy to predict based on the underlying information. The data can be used to forecast automatically without many complications. Any person can easily forecast on the basis of available data.

One of the main disadvantages of this method is its dependence on the data. The entire forecasting depends on the data of the underlying model. An error in the available data can lead to wrong forecasting. These methods can also be used only if the proper data is available. This method cannot also evaluate the effect of changes in the other variables involved. 